\title{
GOOD SEED AND DEEP PLOWING
}

\author{
BY EDGAR DAWSON
}

Field Representative on Civic Education, National Municipal League

It is Prof. Dawson's conviction that much of modern political reform principle is so solidly established that it may properly be made part of primary, high and normal school instruction in civics as it already is in the colleges. He is giving his entire time in 1920 to initiating this movement. $\quad:: \quad$ :: $\quad:: \quad$ : $\quad:: \quad:: \quad:: \quad:: \quad::$

EDucation in sound thinking is the only answer to false propaganda. It has long been a proverb of the educational philosopher that those principles which we would make a part of the thought of the community we must write into the curriculum of the schools. For social and political safety, the teacher must be the moulder of thought. Mr. Roosevelt expressed this idea in one of his cogent aphorisms as follows: "If you are going to do anything permanent with the average man, you have got to begin before he is a man. The chance of success lies in working with the boy, not with the man." We know with what success the Germans followed this principle of education in moulding the public opinion of their people in the support of the kind of principles for which Germany stood. We do not agree with the principles which Germany propagated; but she was so successful in her work that the bloodiest of wars was necessary to check her progress. We do not agree with the principles which the apostles of anarchy and disorganization are now propagating; but unless the weapons of education are used now to check their spread the weapons of force may be required, and may not be effective, against a movement more dangerous to sound economic and political life than even the German propaganda was.

The life America stands for, however half-heartedly we have developed this life, is one of orderly and justly administered government by the majority, however large the territory had in view. We stand for a decent respect for the opinion of mankind as expressed through representativegovernment and organized administration. The principles of organization, the concrete and visible expression of this life, must be made a part of our political thought and action and they must be sincerely and frankly applied unless we wish rising generations to be led away from them into new and untried paths.

At present we are not making use of the best means of propagating the soundest principles of organization for which we stand. We are neglecting our opportunities while the enemy sows the tares. One of the best known of our university professors of political science wrote recently in reply to an inquiry about a wiser method of teaching the principles on which our state governments should be organized to bring them out of the chaos in which so many of us think they now are: "I could hardly agree that the government of the states is in chaos. On the contrary I think that the great difficulty is that it is set on a basis of principles that do not apply,-separation of powers, wholesale election of administrative officers, lack of budget, mass rule in legislation, a weak gov- 
ernor, and an over-strong judicial system. Of course it is a serious business to try to discourage these sacred principles." We need not argue the question whether the writer's quotation describes chaos or not. The word is not important. But that the condition of our state governments is wholly unsatisfactory will be conceded by any thoughtful student of them. Mr. Root calls them "invisible," meaning that they are in such confusion that outside and unknown powers control them. But attention must be called to the sentence in italics, which were not used by the writer quoted. It is said to be a dangerous business to try to educate the youth away from the false principles which account for the inefficiency and invisibility of our government. How shrewd need the false leader be to persuade the untrained citizen that it is time to upset a system in which invisible forces control his destiny?

\section{CLEAN SEED IS READY}

If we are to raise a crop of political thought in this country which will be worth perpetuating we must sow a different kind of seed; we must sow it clean; and we must sow it deep in the life of our community. Let us be concrete. What seeds shall we sow? Who shall sow them? How shall they be sown? What support shall we give to the laborer?

Some fifteen years ago the then leading public educator of the United States was chairman of a committee of the National Municipal League. The task of this committee was to investigate the teaching of municipal government and to report methods of improving it. In summing up the work of the committee, its chairman said that the main difficulty he had found was the fact that teachers did not know what to teach. Thought in this field was in a state of flux; no one knew what a city government should be. This difficulty has now been removed. Through the efforts of the League, the seed has been cleaned. A model city charter has been prepared which expresses the best thought of the country on what a city government should be. If the teacher wishes to prepare for a harvest of confidence in municipal democracy he need only plant the principles of this charter deeply enough in the thought of the rising generation to make them bear fruit when his pupils come to voting age.

But what seed have we for a good crop of ideas on state government? As yet we have no model state constitution, but there is a movement a foot to prepare one. If the movement is successful the work of the teacher will be greatly lightened and his path made much more easy. The preparation of a model state constitution will be largely a matter of formulation and expression, for on the principles which should underlie it, the ablest political scientists are already in general agreement. In fact they correspond very closely with those which were written into the model city charter; with few exceptions, they have already been written into the Constitution of the United States.

\section{INCONTESTIBLE PRINCIPLES}

These principles are already too well known to the readers of the Natronal Municipal Review for them to need elucidation here; but a few of them may be mentioned as illustrations of what the writer of this paper means by the good seed of sound democracy that we must make an earnest effort to sow.

The first principle is that the charter or constitution should be simple and brief enough to be understood and read 
by a well-educated person of average public spirit.

The second is that budgets must be made by the head of the administration which is to spend the public money. This principle is so far-reaching that it involves almost all others.

Executive leadership in a large part of the legislation must go with budgetmaking, for the formulation of policies must go hand in hand with questions of finance.

The principle of the short ballot is now so fully accepted by all thoughtful people that one is constantly astounded that so little effort is made to teach it and thus make its adoption possible in our states. It is, of course, necessary to the formulation of wise budgets, for the departments must work in unison, and this is not practicable unless they work under a head.

Out of the foregoing grows the principle that the administration must be divided into a manageable number of departments. The civil servants in these departments must be differentiated from those whose duty it is to lead in the formulation and execution of policies, and the civil servants must be appointed and promoted on the merit system.

The short ballot principle carries with it an appointive judiciary.

Home rule for each political unit in the solution of its own problems, preferential voting, scientific bill drafting, and the like would all find their places in a system of government such as we need and might easily have.

\section{WHO IS TO TEACH?}

But who is to sow the seed for a fruitful crop of sound political thought, of confident patriotism in a democracy? Whatever answer we may find to this question, the sower must surely understand the principles which he is plant- ing and believe in them. At present, with all our enthusiasm for the teaching of democracy and for training in citizenship, we are assigning our classes in the elements of government to persons whose first interest is the teaching of Latin, mathematics, English, or the training of the athletic teams. Our normal schools, the raison d'étre of which is to train teachers, scarcely pretend to train teachers of government. In fact in many if not most of these there are no classes in the subject. The reader may ask for a more concrete statement of this neglect. It cannot be made more concrete than in the words that follow: Our universities, colleges, training schools, and school administrators are almost totally oblivious of the fact that the study of government has resulted in the formulation of principles which are definite and certain enough to be taught as science to the rising generations. For most of these organs of our educational system the study of politics is a purely academic affair. They are not engaged in the "serious business" of trying to "discourage" "sacred" but utterly false "principles" of political organization. Persons become teachers without ever having heard of the executive budget; they teach the government of the United States without ever referring to it; the pupils graduate in total ignorance of it. In later years when they are busy earning a living they are indifferent to it.

The teaching of hygiene was largely responsible for the enactment of prohibition; the teaching of organized government would prepare the way for efficient and safe democracy. The touchstone of reality for our demand for Americanization is our willingness to demand and financially support such a reorganization of our educational system as will bring every high school child under the guidance for at least a 
year of some teacher who has been trained in the principles of political science.

TIME AND METHOD

If good fortune should at some not too distant day give us trained teachers of government for the schools, we should then be interested in two subordinate problems: First, the pedagogical method, and second, the amount of time that the teacher could claim in the course of study. The Review is not interested in pedagogical methods, but it may be proper to say here that the leading students of child psychology, as applied to the teaching of political ideas and ideals, are in reasonable agreement as to the best methods for this purpose. They need only such support from the training schools and the administrators of education, such as superintendents and principals, as will make it possible to put the methods into practice. The need of trained teachers was mentioned in the paragraph before this. The need of time in which to teach is as important as training in how to teach. At present the work in government is looked upon as a sort of poor relation of history, and history of a very mediocre sort. It is rare that training in principles of government is given as much time in the high school as is training in the principles of physics. Almost never is it given half as much time as training in the forms of language or the principles of mathematics. Yet one might venture to doubt whether the habit of speaking correctly is more important than the habit of thinking correctly on the subject of citizenship. Some are convinced that the former is not twice as important as the latter. Those who administer school systems are not indifferent to their duty, they simply do not realize what their duty is; they do not under- stand that there are principles of government to be taught.

What support shall we give to the laborer? The answer has been suggested in the last two preceding paragraphs. The community must provide in a thoroughgoing way if our crop of citizenship is to be worth any effort. We must select good seed and sow it clean; and we must plow deep not only into the soil we have been using, but we must go down into the subsoil looking far into the future. We must offer salaries in the schools which will attract able persons. We must sternly insist that no one shall enjoy these salaries who has not been thoroughly trained for their work. We must assign in the curriculum enough time and in the budget enough money to make it certain that every pupil who graduates from a high school and thus passes into the leadership of our democracy shall be grounded in those principles which constitute the only safeguard against loose thinking; for loose thinking is the seed-bed of the demagogue, the disorganizer, and the false leader of every sort.

\section{THE SAFETY VALVE}

One paragraph may be added. There are those who will ask what political principles have to do with our economic unrest? The answer is that economic problems are problems of policy. If the young citizen can be given a philosophy on which will rest confidence in his government, in his representative legislature, in his administrative servants, in the judges of his courts, he will rest fairly comfortable in the realization that while all the problems are not solved, the community is doing the best it can to solve them, and that confusion and disorder will not add to the probability that they will be wisely solved. The 